\title{
Petrography and geochemistry of sandstone samples of Vischkuil formation, Karoo Supergroup, South Africa
}

\author{
A. Akinlua ${ }^{1,2}$ - A. Ngola $^{1}$ O. A. Fadipe ${ }^{1}$ S. A. Adekola ${ }^{1,3}$
}

Received: 24 March 2014 / Accepted: 2 August 2015/Published online: 16 November 2015

(C) The Author(s) 2015. This article is published with open access at Springerlink.com

\begin{abstract}
Petrography and geochemistry of sandstones of Vischkuil formation in the Ecca Group of the Karoo Supergroup of South Africa was investigated to evaluate the petroleum potential of its reservoir rock. The petrographic analysis showed that the sandstones were poorly to moderately sorted with evidence of angular to sub-angular grains. The sandstones are lithic arenite. Diagenetic processes on the sandstone include physical and chemical compaction as seen from the straight grain contacts and dissolution of the quartz grains. There is an evidence of pore space reduction by the rearrangement and cementation by silica, calcite and clay minerals. The petrographic analysis also revealed that there is dominance of monocrystalline quartz grains and evidence of cratonic setting derivation. The chemical alteration index ranged from 52.96 to $65.5 \%$, an indication of a moderate weathering at the source area before deposition. The samples are texturally immature, which indicate poor storage capacity for fluids.
\end{abstract}

Keywords Karoo · Vischkuil formation · Petrography · Geochemistry $\cdot$ Sandstone $\cdot$ Reservoir rock

A. Akinlua

geochemresearch@yahoo.com; aakinlua@oauife.edu.ng

1 Department of Earth Sciences, University of the Western Cape, PMB X17, Bellville 7535, Cape Town, South Africa

2 Present Address: Fossil Fuels and Environmental Geochemistry Group, Department of Chemistry, Obafemi Awolowo University, Ile-Ife, Nigeria

3 Present Address: Department of Geology, Obafemi Awolowo University, Ile-Ife, Nigeria

\section{Introduction}

Petrography and geochemistry have been part of the methods used in the evaluation of natural resource of which sandstone is one (Bheemalingeswara and Tadesse 2009). The use of these techniques has become very important in the search for hydrocarbon reservoirs. Petrography and geochemistry studies provide information whether to undertake an in-depth appraisal or not. The combination of petrographic and geochemical data of sedimentary rocks can reveal the nature of source regions, the tectonic setting of the sedimentary basins and the paleoclimate conditions (Jafarzadeh and Hosseini-Barzi 2008). The conditions of formation of a rock can be estimated from the types and textures of its constituent minerals (Dickinson and Suczek 1979). An interpretation of origin is known to rely on field relationship, structure, texture and chemical composition as well as size and proportion of different kind of minerals. Texture, geometry and orientations of grains and voids are the most important features of a rock pertinent to its origin. These features affect density, porosity, permeability, strength, and magnetic behavior (Williams et al. 1982). However, petrographic and geochemical techniques not only enable the systematic description of rocks but also the understanding of their petrogenesis, metamorphism and the ultimate decay of rocks. During weathering, some geochemical ratios can be altered through oxidation (Taylor and McLennan 1985) and/or diagenesis (Nesbit and Young 1989) provided that the bulk composition is not entirely altered. Geochemical analysis is a powerful tool in the study of sandstones (McLennan 1993). Major elements diagrams are used to differentiate the tectonic setting of sedimentary basins. The relative depletion of oxides such as $\mathrm{CaO}$, and $\mathrm{Na}_{2} \mathrm{O}$ and enrichment of $\mathrm{SiO}_{2}$ and $\mathrm{TiO}_{2}$ provides important clues for tectonic setting. These oxides are 
assumed to have depletion or enrichment of quartz, k-feldspar, mica and plagioclase (Bhatia 1983). The main objective of this study is to evaluate the potential of Vischkuil formation sandstones as petroleum reservoir rocks based on the petrographic and geochemical analyses of the sandstones, and also to describe the history leading to the sandstone formation. The study is aimed at evaluation of mineralogical and textural compositions, transport history, geometry of particles, and provenance of detritus and the effect of chemical weathering.

\section{Geologic setting of the study area}

The Karoo basin occupies an area of approximately $66 \%$ of the southern part of the African continent comprising mostly sedimentary rocks of Paleozoic age (Hamilton and Finlay 1928). The Karoo basin is located within longitude $17^{\circ} \mathrm{E}$ and $30^{\circ} \mathrm{E}$ and latitude $25^{\circ} \mathrm{S}$ and $33^{\circ} \mathrm{S}$ (Fig. 1). Its name originated from the main Karoo basin in South Africa, depicting any sedimentary fill formed at the same time across Gondwana (Duncan et al. 1997). Tectonic activities along the southern margin, which were preceded by sedimentation in the Late Carboniferous, led to the construction of the supercontinent. Sedimentation, however, ceased when Pangaea split towards Middle Jurassic (Duncan et al. 1997). However, the Karoo Supergroup strata, mainly shales and sandstones accumulated in a retroarc foreland basin termed "the Karoo basin", attaining a maximum thickness of 12,000 m.

In the southern margin of the basin lies the Cape Fold Belt formed as a result of tectonic activities (compressional forces) during the Late Carboniferous to Late Triassic (Theron 1969; Halbich 1992). The Cape Fold Belt comprises a series of sediments associated with Neoproterozoic and Lower Paleozoic age in the southwestern part of the basin, as well as the granitic rocks (Rozendaal et al. 1999; Da Silva et al. 2000).

The Karoo Supergroup consists of four divisions (Fig. 2), namely the glacial Dwyka Group (Westphalian to Early Permian), Permian Ecca Group (marine), Beaufort (non marine) and Stormberg Groups. These deposits are roofed by volcanic Drakensberg Group (Smith et al. 1998). Visser (1984) described the Ripon formation as a chronostratigraphic equivalent of the Vischkuil and Laingsburg formations to the east of Prince Albert and represents the former lower Ecca stage. The formation consists of alternating sandstone and shale with a maximum thickness of $1 \mathrm{~km}$ (Visser 1984).

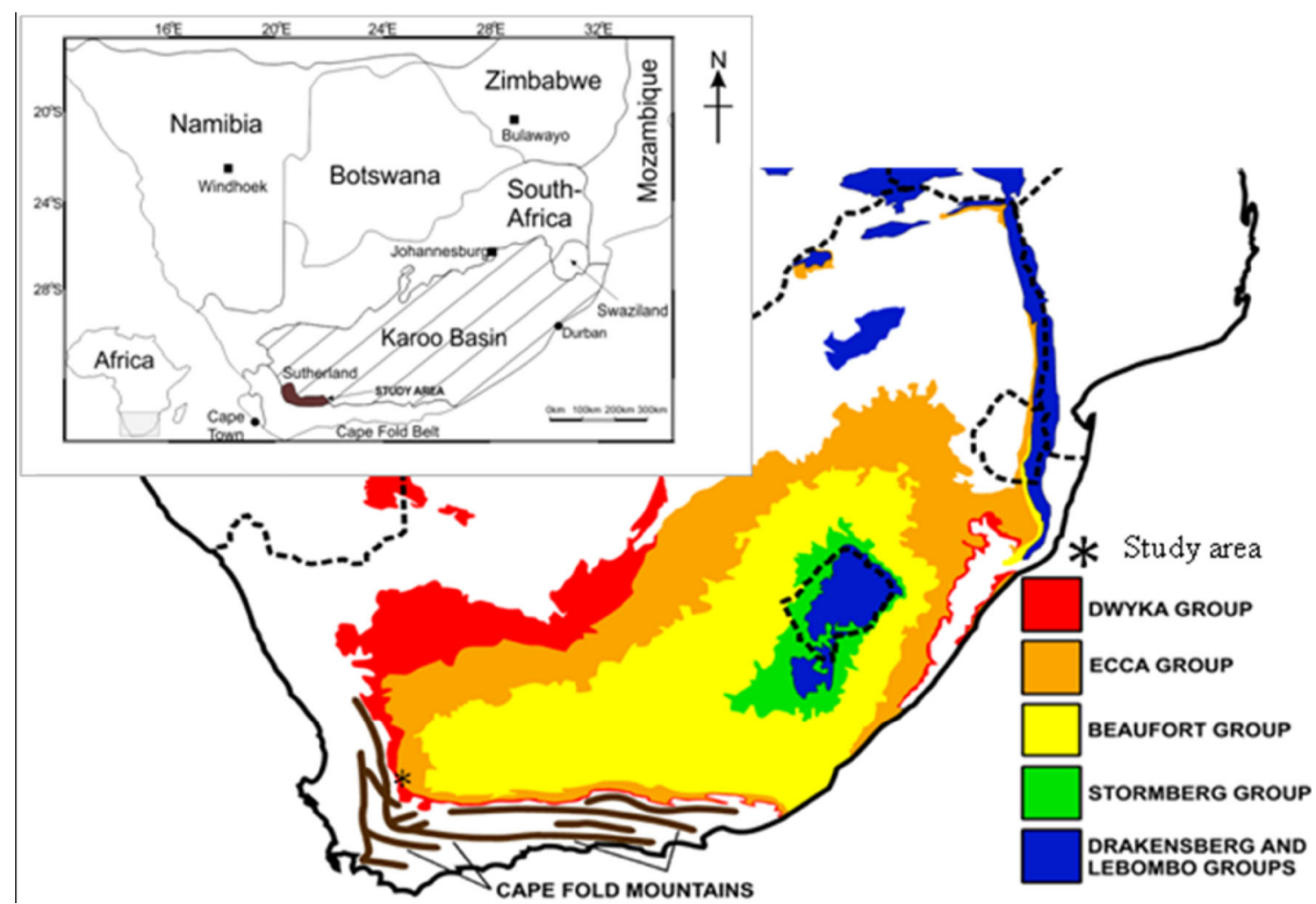

Fig. 1 Geological map of the outcrops of the Karro Supergroups in Southern Africa. Insert is the location map of the study area in the southwest of the Karoo basin, South Africa (modified after Bouma and Wickens, 1994) 


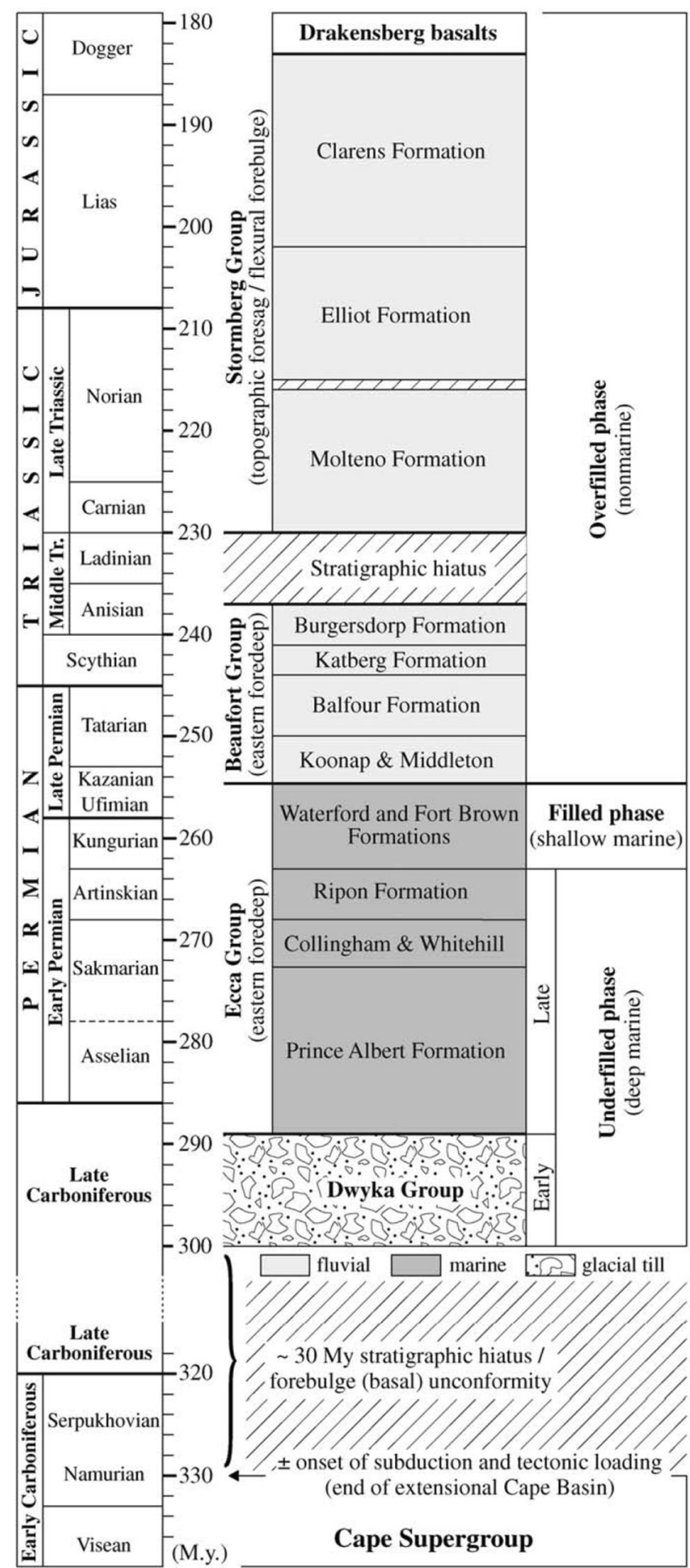

Fig. 2 Karoo Supergroup stratigraphy and its subdivisions in main basin of South Africa. The Vischkuil formation overlies the Collingham formation within the Ecca Group. Ripon formation is equivalent to Vischkuil and Laingsburg formations (after Rubidge 2005)

\section{Materials and methods}

A total of 11 rock samples were collected during field work from different localities within the Vischkuil formation in the Karoo basin. The rock samples were pulverized and homogenized to a size approximately less than $0.3 \mathrm{~mm}$. However, a portion of each sample was prepared for thin section and subsequent petrographic analysis. About $9 \mathrm{~g}$ of each sample was weighed and mixed with $2 \mathrm{~g}$ of binder consisting of 9:1 ratio EMU powder plus C-wax, and shaken thoroughly. The mixture was then placed under 15 tons pressure using a pallet machine and thereof prepared for X-ray fluorescence (XRF) analysis using a Phillips PW 1480 fluorescence spectrometer. Loss on ignition was determined to compensate for the loss of some volatile such as carbon and carbonates during XRF analysis. This was achieved by preparing $0.5 \mathrm{~g}$ of each pulverized sample and heated in an oven at approximately $100{ }^{\circ} \mathrm{C}$ for half an hour. The mixture was allowed to cool and weighed again; thereafter, the mixture was placed in the furnace for $45 \mathrm{~min}$ at approximately $1000^{\circ} \mathrm{C}$, then cooled and weighed again.

\section{Results}

\section{Petrography}

The petrographic investigation of the sandstone samples obtained from Permian Vischkuil formation revealed that the sandstones are mainly characterized by medium to fine grain particles. They are mainly classified as lithic arenites comprising sub-angular to angular and sub-rounded grains (Fig. 3a). They are generally moderate to poor sorted (Fig. 3b) as seen in the thin sections. The main mineralogical constituents include quartz, plagioclase and lithic fragments (Fig. 3c).

Quartz is the most predominant constituent mineral and is present as undulose monocrystalline (MQ) and polycrystalline grains (PQ). The monocrystalline quartz grains range from sub-rounded to sub-angular (Fig. 3d, e), whereas the polycrystalline quartz grains vary from subangular to angular (Fig. 3e). The grain contacts are straight to suture (Fig. 3g).

Two types of feldspars have been identified (Table 1). Plagioclase and k-feldspars are present throughout the samples. Plagioclase grains vary in size, from small to large with euhedral shape. The feldspars include albite (plagioclase), orthoclase and microcline (k-feldspars). Albite is more abundant than its counterpart orthoclase and microcline. Twinning is prominent (Fig. 3d, h).

In general, the fragments are sub-rounded and sub-angular to angular. However, few rounded fragments were observed, and they are mainly clasts of quartz and feldspars, with calcite present as cementing material (Fig. 3k). Syntaxial patches of brownish concretions were observed (Fig. 3i). Other rock fragments include heavy minerals such as kyanite, merwinite, biotite and mica (Fig. 3i, j, n). 

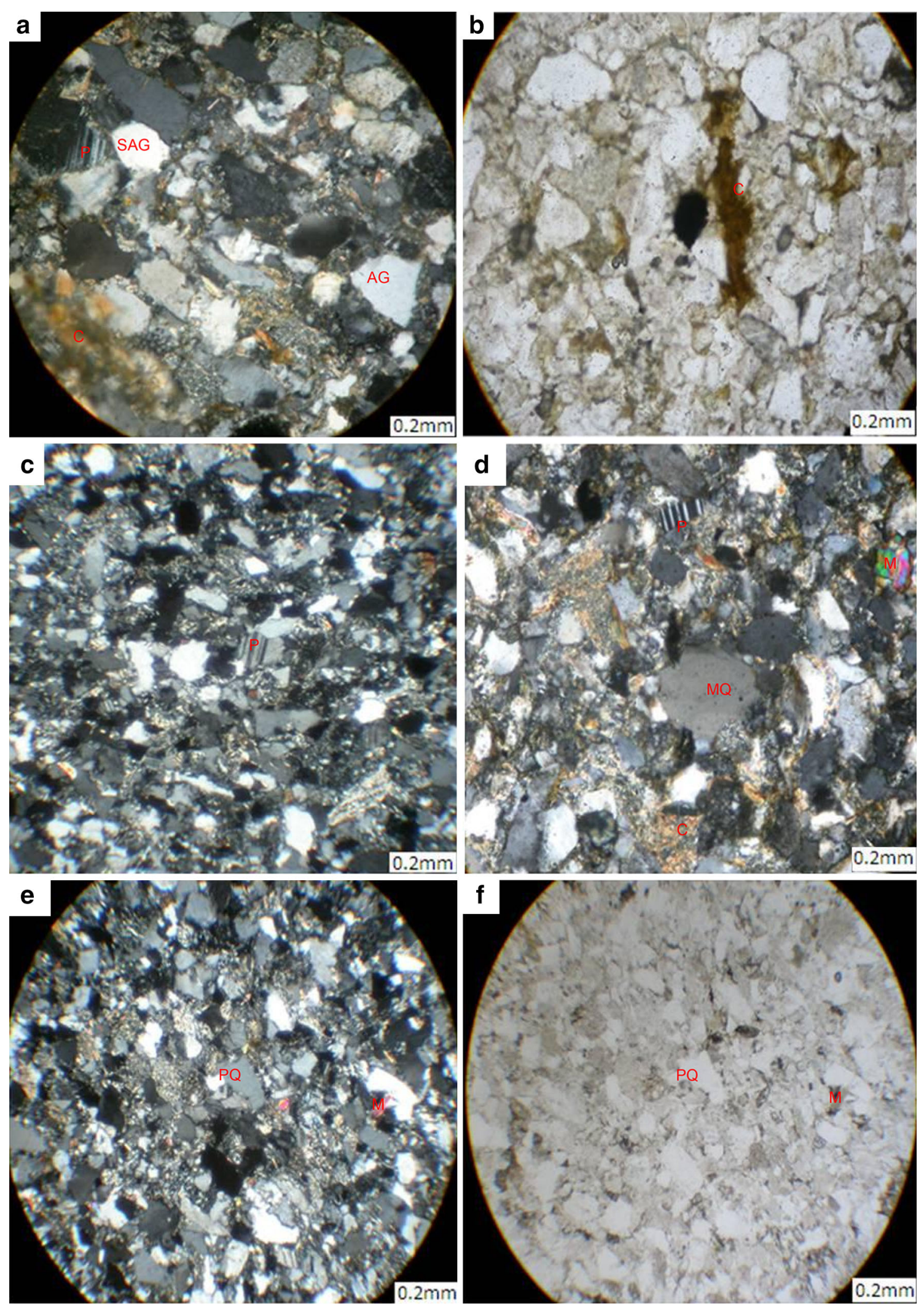

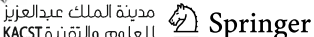


4Fig. 3 Thin-section photomicrographs illustrating the morphology of the sandstone samples from the Karoo basin. $M$ mica, $P$ plagioclase, $M Q$ undulose monocrystalline quartz, $P Q$ polycrystalline quartz, $C$ concretion, $A G$ Angular grain, $S A G$ sub-angular grain. a The photomicrograph of sandstone sample viewed under cross polarized light $(X P)$ showing $C, P, S A G$ and $A G$. Optical photomicrograph showing tightly packed grains with some concretional material filling the available pore spaces. b The photomicrograph of sandstone sample viewed under plane polarized (PP) light showing the concretion distribution and degree of sorting. The particles are well packed and the shape ranges from angular to sub-rounded with concretion material filling pore spaces available. c The photomicrograph of sandstone sample viewed under XP showing fragment of rocks, including quartz and plagioclase. The slide shows evidences of quartz fragment with over growth of quartz. There are also developments of some secondary porosity. d The photomicrograph of sandstone sample viewed under PP showing $P, M, C$ and $M Q$. The developed secondary porosities $\mathbf{c}$ are seen sealed by concretion materials. e The photomicrograph of sandstone sample viewed under $\mathrm{XP}$ showing polycrystalline quartz and mica. Various shapes and sizes of the quartz materials are seen in this slide with specs of mica. There are evidences of secondary porosities development. f The photomicrograph of sandstone sample viewed under PP showing polycrystalline quartz and mica. The developed porosities in e are seen seal up by calcite cement under plane polarized light. $\mathrm{g}$ The photomicrograph of sandstone sample viewed under XP showing straight contact (black arrow) and pore spaces not interconnected. There is presence of close-up of quartz materials with some twinned calcite cement holding materials together to impede porosity. $\mathbf{h}$ The photomicrograph of sandstone sample viewed under XP showing plagioclase feldspar displaying twinning property. The description as seen in $\mathbf{g}$ but with some presence of few plagioclase feldspars. $\mathbf{i}$ The photomicrograph showing concretion under XP. The materials are well packed with the concretion materials filling available pore space. $\mathbf{j}$ The photomicrograph of clay minerals under PP. Same as in $\mathbf{j}$ but the cementing material is clay mineral in this case. $\mathbf{k}$ Calcite cement distribution (red arrows) under XP. The calcite cement is seen holding the material together thereby blocking all available pore spaces. I Kyanite mineral (blue arrow) in a XP. The kyanite mineral is showing an imprint on all the existing materials and indication post sedimentation process. m Biotite (blue arrow) mineral showing elongated shape possibly as a result of deformation in PL. $\mathbf{n}$ Elongated mica (blue arrow) mineral resulting from deformational events under $\mathrm{XP}$

\section{Geochemistry}

All the samples except VS $11(41.10 \%)$ show high concentrations of $\mathrm{SiO}_{2}$ which ranges from 66.21 to $73.13 \%$ and lower concentrations of $\mathrm{SO}_{3}$ that ranges from 0.0062 to $0.025 \%, \mathrm{MnO}$ concentration ranges from 0.071 to $0.12 \%$, $\mathrm{P}_{2} \mathrm{O}_{5}$ concentration ranges from 0.11 to $0.20 \%$ and $\mathrm{TiO}_{2}$ concentration ranges from 0.60 to $0.83 \%$. VS 11 has the lowest concentration values for all major elements except for $\mathrm{MnO}$ and $\mathrm{CaO}$ where it recorded the highest concentration values of 1.05 and $27.89 \%$, respectively (Table 1). The order of abundance of the oxides is $\mathrm{SiO}_{2}, \mathrm{Al}_{2} \mathrm{O}_{3}$, $\mathrm{Fe}_{2} \mathrm{O}_{3}, \mathrm{CaO}, \mathrm{K}_{2} \mathrm{O}, \mathrm{MgO}, \mathrm{Na}_{2} \mathrm{O}, \mathrm{TiO}_{2}, \mathrm{P}_{2} \mathrm{O}_{5}, \mathrm{MnO}$ and $\mathrm{SO}_{3}$.

Minor variation in concentration values was observed in $\mathrm{P}_{2} \mathrm{O}_{5}, \mathrm{SO}_{3}, \mathrm{MnO}$ and $\mathrm{MgO}$, particularly on VS 11 (Table 1;
Fig. 3i, k). Conversely, major variations occur in all samples for $\mathrm{CaO}$ and $\mathrm{K}_{2} \mathrm{O}, \mathrm{Al}_{2} \mathrm{O}_{3}$ and $\mathrm{Fe}_{2} \mathrm{O}_{3}$ (Table 1). There is, however, an inverse relationship between $\mathrm{SiO}_{2}$ and $\mathrm{CaO}$ (Table 1). The predominance of $\mathrm{CaO}+\mathrm{Na}_{2} \mathrm{O}$ in relation to $\mathrm{K}_{2} \mathrm{O}$ can probably be attributed to high $\mathrm{Ca}$-feldspar and $\mathrm{Na}$-feldspar content amongst the sandstone. The low value of $\mathrm{K}_{2} \mathrm{O}$ compared the two oxide earlier discussed may be due to low concentration of the oxide in the source area. The plagioclase is seen to predominate in the thin sections when compared with orthoclase feldspar (Fig. 3a, c, d, h).

\section{Discussion}

Based on petrographic analysis, chemical composition and visual examination, the studied sandstones of the Vischkuil formation are classified as lithic arenites (Fig. 4) and they show high contents of silica (Table 1) except VS 11, which is characterized by rounded particles, (Fig. 3a). The silica $\left(\mathrm{SiO}_{2}\right)$ may have been derived from quartz (pressure solution), alteration of feldspars and other clay minerals present.

Concentrations of $\mathrm{Al}_{2} \mathrm{O}_{3}$ and $\mathrm{K}_{2} \mathrm{O}$ may relate to the presence of $\mathrm{k}$-feldspars (orthoclase and microcline), illite and mica. The source of $\mathrm{Na}_{2} \mathrm{O}$ is mainly related to the presence of plagioclase feldspar (albite). $\mathrm{CaO}$ concentration may relate to the presence of calcite $\left(\mathrm{CaCO}_{3}\right)$ (Fig. 3k). High iron content may be explained due to the presence of heavy minerals observed under the microscope, and to some extent the presence of iron bearing clay mineral (Fe) (Fig. 3j). The source of magnesium oxide $(\mathrm{MgO})$ may be linked with the presence of chlorite.

The investigation revealed that these sandstones are fine (VS 1, VS 2, VS 3, VS 6, VS 7, VS 9 and VS 11) to medium grain (VS 4, VS 5 and VS 8), with variation in sorting and shapes. Sandstone with moderate sorting and admixture of grain sizes is expected to have lower porosity and poor permeability which affects their reservoir properties. Nevertheless, these variations are characterized by the extent to which the sediments were transported. Usually, well-rounded and sorted grains indicate that sediments were transported for a long distance from its source (Hussain et al. 2006), whereas the sub-rounded and poorly sorted grains imply short distance of transportation (Hussain et al. 2006). This transportation history suggests that the sediment based on the sub-rounded to sub-angular shapes as seen on thin sections is an indication of an extensive reworking, implying a cratonic or a recycled source (Al-Harbi and Khan 2008). The minute amount of feldspars and lithic fragments in these samples also indicates a cratonic source as well as a moderate degree of chemical weathering (Table 1). The abundance of monocrystalline quartz grains reflects a cratonic or recycled source (Al-Harbi and Khan 2008). 
Fig. 3 continued

Fig. 3 contined
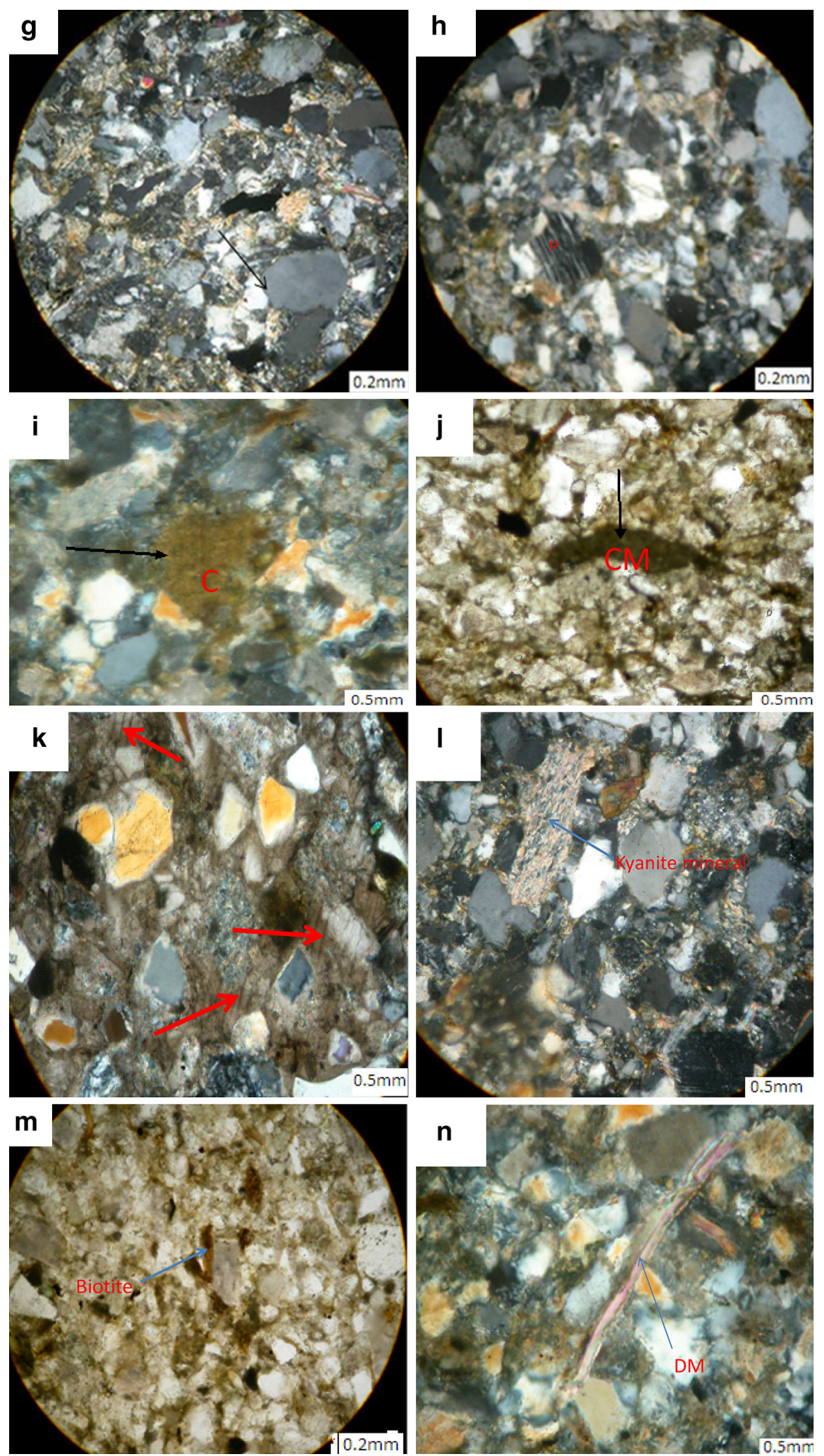
Table 1 Major elements analysis of sandstones of Vischkuil formation

\begin{tabular}{|c|c|c|c|c|c|c|c|c|c|c|c|c|c|c|}
\hline $\begin{array}{l}\text { Sample } \\
\text { ID }\end{array}$ & $\begin{array}{l}\mathrm{SiO}_{2} \\
(\%)\end{array}$ & $\begin{array}{l}\mathrm{Al}_{2} \mathrm{O}_{3} \\
(\%)\end{array}$ & $\begin{array}{l}\mathrm{Fe}_{2} \mathrm{O}_{3} \\
(\%)\end{array}$ & $\begin{array}{l}\mathrm{MnO} \\
(\%)\end{array}$ & $\begin{array}{l}\mathrm{MgO} \\
(\%)\end{array}$ & $\begin{array}{l}\mathrm{CaO} \\
(\%)\end{array}$ & $\begin{array}{l}\mathrm{Na}_{2} \mathrm{O} \\
(\%)\end{array}$ & $\begin{array}{l}\mathrm{K}_{2} \mathrm{O} \\
(\%)\end{array}$ & $\begin{array}{l}\mathrm{P}_{2} \mathrm{O}_{5} \\
(\%)\end{array}$ & $\begin{array}{l}\mathrm{TiO}_{2} \\
(\%)\end{array}$ & $\begin{array}{l}\mathrm{SO}_{3} \\
(\%)\end{array}$ & $\begin{array}{l}\text { LOI } \\
(\%)\end{array}$ & $\begin{array}{l}\text { Sum } \\
(\%)\end{array}$ & $\begin{array}{l}\text { CIA } \\
(\%)\end{array}$ \\
\hline VS 1 & 61.21 & 12.36 & 7.39 & 0.12 & 2.04 & 2.63 & 2.12 & 3.6 & 0.17 & 0.76 & 0.02 & 2.59 & 100 & 59.7 \\
\hline VS 2 & 69.46 & 11.78 & 5.98 & 0.09 & 2.27 & 1.98 & 2.25 & 2.98 & 0.2 & 0.8 & 0.02 & 2.21 & 100 & 62.02 \\
\hline VS 3 & 69.69 & 11.2 & 6.35 & 0.09 & 1.9 & 2.2 & 2.24 & 3.01 & 0.18 & 0.82 & 0.02 & 2.29 & 100 & 60.09 \\
\hline VS 4 & 70.36 & 12.21 & 5.25 & 0.08 & 1.96 & 1.93 & 2.27 & 2.98 & 0.17 & 0.77 & 0.02 & 2 & 100 & 62.96 \\
\hline VS 5 & 69.86 & 12.2 & 5.4 & 0.08 & 2.04 & 1.55 & 2.42 & 3.15 & 0.19 & 0.81 & 0.02 & 2.29 & 100 & 63.17 \\
\hline VS 6 & 68.8 & 12.23 & 6.5 & 0.96 & 2.35 & 1.18 & 2.31 & 3.13 & 0.17 & 0.73 & 0.01 & 2.5 & 100 & 64.86 \\
\hline VS 7 & 70.2 & 12.14 & 5.24 & 0.07 & 2.1 & 1.38 & 2.52 & 3.05 & 0.2 & 0.79 & 0.03 & 2.3 & 100 & 63.6 \\
\hline VS 8 & 70.83 & 11.2 & 5.83 & 0.08 & 1.83 & 1.69 & 2.22 & 3.12 & 0.17 & 0.8 & 0.01 & 2.2 & 100 & 61.41 \\
\hline VS 9 & 72.89 & 9.68 & 4.31 & 0.07 & 1.39 & 3.14 & 2.29 & 2.76 & 0.17 & 0.71 & 0.02 & 2.58 & 100 & 54.17 \\
\hline VS 10 & 70.98 & 11.18 & 4.98 & 0.76 & 1.8 & 2.4 & 2.48 & 2.69 & 0.17 & 0.75 & 0.04 & 2.48 & 100 & 59.64 \\
\hline VS 11 & 41.1 & 7.64 & 1.88 & 1.05 & 1.2 & 27.8 & 1.76 & 2.42 & 0.11 & 0.61 & 0.02 & 2.41 & 100 & 19.28 \\
\hline
\end{tabular}

CIA chemical index of alteration, LOI loss on ignition

Fig. 4 Chemical classification of sandstones based on $\log$ $\left(\mathrm{Na}_{2} \mathrm{O} / \mathrm{K}_{2} \mathrm{O}\right)$ vs. $\log \left(\mathrm{SiO}_{2} /\right.$ $\mathrm{Al}_{2} \mathrm{O}_{3}$ ) diagram of Pettijohn et al. (1972)

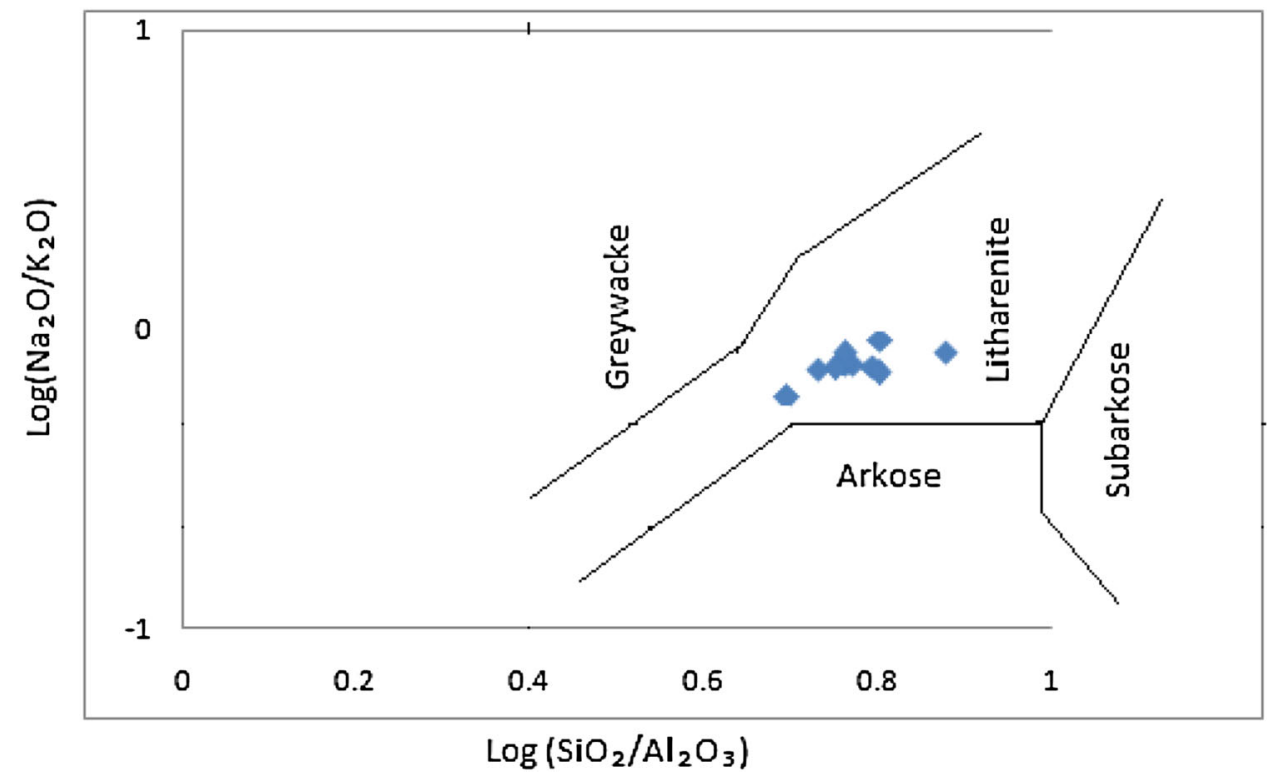

The chemical index of alteration (CIA) of these samples was determined using the formula of Nesbit and Young (1982) which states that $\mathrm{CIA}=\left\{\mathrm{Al}_{2} \mathrm{O}_{3} /\left(\mathrm{Al}_{2} \mathrm{O}_{3}+\right.\right.$ $\left.\left.\mathrm{CaO}+\mathrm{K}_{2} \mathrm{O}\right)\right\} \times 100$. The result shows variations in values, these variations may imply changes in the proportion of feldspars and other clay minerals. The lower CIA value in VS 11 (Table 1) suggests that it was less exposed to weathering relative to other samples, and subsequently feldspars and other clay minerals are high compared to the rest of the samples. However, most of the samples have a CIA value ranging from 59.70 to $65.51 \%$ with an average of $55.79 \%$, thus indicating that these sandstones underwent a moderate degree of weathering leading particularly to reduction of some alkalis and alkaline earth metals and enhancement of $\mathrm{Al}_{2} \mathrm{O}_{3}$ (Al-Harbi and Khan 2008). The following assumptions were made on CIA determination; $\mathrm{CaO}$ is considered as the amount of $\mathrm{CaO}$ incorporated in the silicate fraction of the rock. Correction for $\mathrm{CaO}$ from carbonate contribution could not be done because of availability of $\mathrm{CO}_{2}$ values. To achieve this, the assumption of Bock et al. 1998 was adopted. They stated that to use the value of $\mathrm{CaO}$, the value must be less than the value $\mathrm{Na}_{2} \mathrm{O}$ (Table 1).

The studied sandstones of the Vischkuil formation have undergone diagenesis leading mainly to reduction of feldspars and unstable lithic fragments forming new clay minerals (Fig. 3j). Silica cement is more abundant than the other cements and it is present throughout the formation. 
Silica may have been sourced from alteration of feldspars and from quartz dust abraded during transportation in the early diagenesis or from pressure solution during later diagenesis (Selley 1997).

Carbonate cements are very common in sandstones and are the main cause of permeability and porosity reduction. Calcite $\left(\mathrm{CaCO}_{3}\right)$ is the main carbonate cement identified in these sandstones, and it is present as syntaxial patches (Fig. 3k). Calcite may form as precipitates from dissolution of shelly material in sediments (Al-Harbi and Khan 2008). Furthermore, calcite cement has the tendency to fill the intergranular pore space.

Weathering or hydrothermal alteration of muscovite identified (Fig. 3n) or feldspars (Adams et al. 1984) may result in formation of clay mainly as chlorite and illite. They occur throughout the studied sandstone samples. Illite forms hair-like threads and matted webs, and it tends to reduce permeability and porosity (Al-Harbi and Khan 2008). Chlorite on the other hand has a variety of forms including platy, honeycomb, rosette crystals and it reduces both permeability and porosity (Selley 1997). The presence of these clays and other cements (calcite and silica) destroys the potential of a good reservoir as they block the pore spaces for the accumulation and flow of fluids.

\section{Conclusion}

The studied sandstones of the Vischkuil formation are classified as lithic arenites, and have experienced diagenetic processes characterized by cementation, dissolution and leaching. Silica, carbonate, clay and iron oxides are present in these sandstones. The occurrence of dissolution and leaching processes is documented by carbonate cement, alteration of feldspars and possibly the influx of meteoric water or organic acids from the adjacent lithology, shale in particular. The samples have a CIA values ranging from 59.70 to $65.51 \%$ with an average of $55.79 \%$. Thus, indicating that these sandstones undergone a moderate degree of weathering leading particularly to reduction of some alkalis and alkaline earth metals and enhancement of $\mathrm{Al}_{2} \mathrm{O}_{3}$. This fact is also supported by the presence of plagioclase feldspar as observed in thin sections.

The grain size and particle geometry as well as degree of sorting of the studied sandstones indicate that they are texturally immature to sub-mature. Hence, porosity and permeability are lower, suggesting a poor reservoir quality.

The presence of chlorite, biotite and mica indicates that these sandstones have experienced low-grade metamorphism that also confirms the litharenite type of sandstone with lot of MQ and PQ. Clays, silica and calcite cements are the main cause of porosity and permeability reduction of these sandstones and therefore they may be responsible for the poor reservoir quality.

Open Access This article is distributed under the terms of the Creative Commons Attribution 4.0 International License (http:// creativecommons.org/licenses/by/4.0/), which permits unrestricted use, distribution, and reproduction in any medium, provided you give appropriate credit to the original author(s) and the source, provide a link to the Creative Commons license, and indicate if changes were made.

\section{References}

Adams AE, Mackenzie WS, Guilford C (1984) Atlas of sedimentary rocks under the microscope, 1st edn. Prentice Hall, New Jersey, USA

Al-Harbi OA, Khan M (2008) Provenance, diagenesis, tectonic setting and geochemistry of Tawil sandstone (Lower Devonian) in Central Saudi Arabia. J Asian Earth Sci 33:278-287

Bhatia MR (1983) Plate tectonics and geochemical composition of sandstone. J Geol J 91:611-627

Bheemalingeswara K, Tadesse N (2009) Petrographic and geochemical study of low grade metamorphic rocks around negash with reference to base metal mineralization and ground water quality, Tigray, Northern Ethiopia. J Geol 2:106-132

Bock B, McLennan SM, Hanson GN (1998) Geochemistry and provenance of the Middle Ordovician Austin Glen Member (Normanskill formation) and the Taconian Orogeny in New England. Sedimentology 45:635-655

Bouma AH, Wickens H deV (1994) Tanqua Karoo, ancient analog for fine-grained submarine fans. In: Weimer P, Bouma $\mathrm{AH}$, Perkins BF (eds) Submarine fans turbidite systems. GCSSEPM fifteenth research conference, pp 23-24

Da Silva LC, Gresse PG, Scheeper R, McNaughton NJ, Hartmann LA, Fletcher I (2000) U-Pb and Sm-Nb age constrains on the timing and source of Pan-African Cape granite suite, South Africa. J Afr Earth Sci 30:395-815

Dickinson WR, Suczek CA (1979) Plate tectonics and sandstones compositions. AAPG Bull 63:2164-2192

Duncan RA, Hooper PR, Rehacek J, Marsh JS (1997) The timing and duration of the Karoo igneous event, southern Godwana. J Geophys Res 102:18127-18138

Halbich IW (1992) The cape fold belt orogeny: state of art 1970s1980s. In: de Wit MJ, Ransome IGD (eds) Inversion tectonics of the Cape Fold Belt, Karoo and Cretaceous basins of Southern Africa. Balkema, Rotterdam, pp 144-158

Hamilton GNG, Finlay JG (1928) Outline of geology for South African students. Central News Agency Ltd., Johannesburg

Hussain M, El Hassan WM, Abdulraheen A (2006) Control of grain size distribution on geochemical properties of reservoir rocks-a case study: cretaceous Kahafji member, Zuluf field, offshore Arabian Gulf. Mar Pet Geol 23:703-713

Jafarzadeh M, Hosseini-Barzi M (2008) Petrography and geochemistry of Ahwag sandstone member of Asmari formation, Zagro, Iran: implications on provenance and tectonic setting. Rev Mex de Sci Geol 25:247-312

McLennan SM (1993) Weathering and global denudation. J Geol 101:295-303

Nesbit HW, Young GM (1982) Early Proterozoic climates and plate motions inferred from major element geochemistry of lutites. Nature 299:715-717

Nesbit HW, Young GM (1989) Formation and diagenesis of weathering profiles. J Geol 97:129-147

Pettijohn FJ, Potter PE, Siever R (1972) Sand and sandstones. Springer, New York, p 618 
Rozendaal A, Gresse PG, Scheeper R, Le Roux JP (1999) Neoproterozoic to early Cambrian crustal evolution of Pan African Saldania belt, South Africa. Precambrian Res 97:303-323

Rubidge BS (2005) Reuniting lost continents-fossil reptiles from the ancient Karoo and their wanderlust. South Afr J Geol 108:135-172

Selley RC (1997) The basins of Northwest Africa: structural evolution. In: Selley RC (ed) African basins. Elsevier, Amsterdam, pp 17-26

Smith RMH, Turner BR, Hancox PJ, Rubidge BS, Catuneanu O (1998) Trans-Karoo II: 100 million years of changing terrestrial environments in the main Karoo basin. Guide book Gondwana10th international conference, University of Cape Town, South Africa, p 117
Taylor RS, McLennan SM (1985) The continental crust: its composition and evolution. Blackwell, Oxford, p 312

Theron JN (1969) The Bavianskloof range-a Southern African nappe. South Afr J Geol 72:29-30

Visser JNJ (1984) The geology of republic of South Africa, Transkei, Bophuthatswana, Venda and Ciskei and kingdoms of Lesotho and Swaziland, 4th edn. Geological survey of South Africa, South Africa

Williams H, Turner FJ, Gilbert CM (1982) Petrography: an introduction to the study of rocks in thin sections. W. H. Freeman, San Francisco 